\title{
Stability of the pigmentation of egg yolks enriched with omega-3 and carophyll stored at room temperature and under refrigeration
}

\author{
Vanessa Camarinha Barbosa ${ }^{1}$, Arlene Gaspar ${ }^{2}$, Ligia Fátima Lima Calixto ${ }^{3}$, Tarcísio Simões \\ Pereira Agostinho 4
}

\footnotetext{
${ }^{1}$ Mestranda do Programa de Pós-graduação em Ciência e Tecnologia de Alimentos da UFRRJ.

2 Departamento de Tecnologia de Alimentos - Instituto de Tecnologia - UFRRJ.

${ }^{3}$ Departamento de Zootecnia - Instituto de Zootecnia - UFRRJ.

${ }^{4}$ Mestrando no Programa de Pós-graduação em Zootecnia da UFRRJ - Universidade Federal Rural do Rio de Janeiro (UFRRJ) BR 465, Km 7 - Seropédica - Rio de Janeiro - 23890-000.
}

\begin{abstract}
The objective of this experiment was to study yolk pigmentation stability in omega $3(\omega-3)$ enriched eggs stored under different temperatures in zeaxanthin equivalent (by using visible light spectrophotometer) and visual score (with values obtained by yolk color fan) and to verify the correlation among those methodologies. Three hundred big eggs from Isa Brown hens were distributed into two lots each one containing 150 eggs, stored at room temperature $\left(26.5^{\circ} \mathrm{C}\right)$ or under refrigeration $\left(7.9^{\circ} \mathrm{C}\right.$ ) for 35 days. It was used a completely randomized design in a $2 \times 6$ factorial arrangement (storage temperature $\times$ storage period). Pigmentation observed with the yolk color fan was steady during the experiment period when eggs were kept under refrigeration and it reduced when stored at room temperature. At spectrophotometric quantification, carotenoids decreased in both temperatures studied. There is a high correlation between the methods of analysis for eggs stored at room temperature and for eggs stored under refrigeration as well, but this correlation is sharper when eggs are stored under refrigeration.
\end{abstract}

Key Words: carotenoids, colour fan, spectrophotometer, yolk

\section{Introduction}

The pigment found in egg yolk determines the acceptability of the product by the consumer who prefers yellow-orange egg yolk. The yellow pigment is mainly explained by the presence of xanthophylls derived from carotenoids (Linden \& Lorient, 1996; Biscaro \& CanniattiBrazaca, 2006).

Carotenoids are important in the poultry nutrition because they are controlled by the diet (Bornstein \& Bartov, 1966). Some ingredients used for eggs enrichment with polyunsaturated $\omega-3$ fatty acids are natural sources of carotenoids and their use in diets of laying hens promotes greater yolk pigmentation (Carvalho et al., 2006; Cedro et al., 2009).

According to Rech (2009), yellow corn based diets contribute to the production of eggs with yellow yolks whereas diets with low corn pigmentation, sorghum grain and wheat, with no added dyes, produce eggs with a low yellow pigmentation. In order to change the yolk pigmentation, some ingredients can be added to the diets, such as natural dyes (like as annatto and paprika) and synthetic carotenoids, such as canthaxanthin (red pigment) and ethyl ester beta apo-8- carotene (yellow pigment).
The main carotenoids found in maize are the xanthophylls lutein and zeaxanthin (Lemos et al., 2006). Carotenoids contain large numbers of double bonds in their molecules and because of this they may oxidade depending on storage time, room temperature and the effect of lighting. Even the processes of harvesting and milling of corn may compromise the amount of these pigments and impair the absorption and deposition of carotenoids by birds in body tissues, especially egg yolk (El Boushy \& Raterink, 1992).

The objective of this experiment was to evaluate the stability of the pigmentation of yolks of $\omega-3$ enriched eggs stored under different temperatures by using zeaxanthin equivalent (using visible light spectrophotometer) and visual score (with values obtained by yolk colour fan) and to verify the correlation among those methods.

\section{Material and Methods}

Three hundred $\omega-3$ enriched eggs were randomly collected on Shintaku farm, located in Marília, SP, Brazil. The eggs were from Isa Brown commercial layers, large type with brown bark. Five birds were housed per $45 \times 50 \times 45 \mathrm{~cm}$ cage $\left(450 \mathrm{~cm}^{2} / \mathrm{bird}\right)$ at the farm. From the $22^{\text {nd }}$ week of age, the hens were fed diets containing $1.5 \%$ 
powder substrate and $1.8 \%$ of the liquid oil fraction rich in $\omega-3$ (Table 1), with an oleic fraction composed predominantly of linseed oil.

After collecting, eggs were packed in cardboard trays and transported in a non-refrigerated truck from the farm (Marília, SP) to the laboratory (Seropédica, RJ). The time spent from egg collection on the farm to the arrival at the laboratory was four days.

Upon arrival at the laboratory, the eggs were divided into two batches of 150 eggs, classified as Lot A and Lot B. The A lot eggs were stored at room temperature $\left(26.5^{\circ} \mathrm{C}\right)$ and $56 \%$ of air relative humidity (non refrigerated eggs) whereas the B lot eggs were maintained under refrigeration $\left(7.9^{\circ} \mathrm{C}\right.$ ) with $29 \%$ of humidity (refrigerated eggs).

Analyses were immediately performed on each batch (time zero) and continued on the $7^{\text {th }}, 14^{\text {th }}, 2^{\text {nd }}, 28^{\text {th }}$ and $35^{\text {th }}$ storage days, randomly analyzing ten eggs from each storage temperature for each analysis day, considering each egg one repetition.

The visual assessment of the yolk pigmentation intensity was performed individually by three people. The eggs were broken in flat glass and the yolk was manually separated from the albumen. The degree of yolk pigmentation

Table 1 - Composition of hen diets

\begin{tabular}{|c|c|}
\hline Ingredient & $\begin{array}{c}\text { Quantity } \\
(\mathrm{kg} / 100 \mathrm{~kg})\end{array}$ \\
\hline Corn & 56.64 \\
\hline Soybean meal (46\%) (46\%) & 25.20 \\
\hline Meat and bone flour & 5.70 \\
\hline Thick limestone & 4.20 \\
\hline Limestone powder & 4.10 \\
\hline Salt & 0.30 \\
\hline Uninúcleo pufa $\omega-3 \mathrm{FL}^{\circledR}$ (oil fraction) $^{3}$ & 1.80 \\
\hline Uninúcleo pufa $\omega-3 \mathrm{ST}^{\circledR}\left(\right.$ powder premix) ${ }^{3}$ & 1.50 \\
\hline Vitamin supplement ${ }^{2}$ & 0.10 \\
\hline Methionine $(84 \%)$ & 0.14 \\
\hline Lisin - $\mathrm{HCl}(78 \%)$ & 0.05 \\
\hline Choline chloride $(60 \%)$ & 0.05 \\
\hline Endo-power $\beta^{\circledR}$ & 0.015 \\
\hline Mineral suplement ${ }^{3}$ & 0.10 \\
\hline Carophyll (canthaxanthin dye-based) & 0.003 \\
\hline \multicolumn{2}{|l|}{ Calculated composition } \\
\hline Metabolizable energy (kcal/kg) & 2,620 \\
\hline Crude protein $(\%)$ & 18.38 \\
\hline Crude fat $(\%)$ & 4.77 \\
\hline Crude fiber $(\%)$ & 2.67 \\
\hline Ash (\%) & 12.52 \\
\hline Calcium (\%) & 4.04 \\
\hline Total phosphorus (\%) & 0.64 \\
\hline \multicolumn{2}{|c|}{$\begin{array}{l}{ }^{1} \text { Data provided by the Farm where the eggs were collected. } \\
{ }^{2} \text { Composition: vit. A - } 8,000,000 \mathrm{UI} \text {; vit. D3 }-3,000,000 \mathrm{UI} \text {; vit. E }-15,000 \mathrm{UI} \text {; } \\
\text { vit. K3 }-2,000 \mathrm{mg} \text {; vit. B2 }-4,000 \mathrm{mg} \text {; vit. B }-1,000 \mathrm{mg} \text {; vit. B } 12-10,000 \mathrm{mcg} \text {; } \\
\text { folic acid }-200 \mathrm{mg} \text {; pantotenic acid }-5,350 \mathrm{mcg} \text {; antioxidant (BHT) }-100,000 \mathrm{mg} \text {; } \\
\text { selenium }-170 \mathrm{mg} \text {. } \\
{ }^{3} \text { Manganese }-68.4 \mathrm{~g} / \mathrm{kg} \text {; zinc }-54.0 \mathrm{~g} / \mathrm{kg} \text {; iron }-54.0 \mathrm{~g} / \mathrm{kg} \text {; cuprum }-9.0 \mathrm{~g} / \mathrm{kg} \text {; } \\
\text { iodine }-1.0 \mathrm{~g} / \mathrm{kg} \text {; cobalt }-0.495 \mathrm{~g} / \mathrm{kg} \text {; selenium }-0.306 \mathrm{~g} / \mathrm{kg} \text {. }\end{array}$} \\
\hline
\end{tabular}

was observed in each egg with yolk colour fan $\mathrm{DSM}^{\circledR}$, which has a range of values of colour intensity from 1 to 15 points. This scale consists of a colour gradient that starts at light yellow (value 1) and ends at orange (value 15). In this analysis, ten eggs from each storage temperature were randomly analyzed, considering each egg one repetition.

Carotenoids were determined in triplicate in zeaxanthin equivalents according to the method proposed by Rodriguez-Amaya (1999) but with some changes. A pool was made with the yolks analyzed with colour fan. About $3 \mathrm{~g}$ of yolk were weighed in triplicate, crushed with the aid of Celite ${ }^{\circledR}$ (for increased friction) in a mortar and pestle, cold acetone was added and the mixture remained resting for 5 minutes. Then, the mixture was filtreted with a sintered glass attached to a kitassato, repeating this operation until the exhaustive extraction of carotenoids, which remained in kitassato with acetone.

For the solvent partition, $15 \mathrm{~mL}$ of petroleum ether was added to a separatory funnel. Then the filtrate previously obtained (carotenoids + acetone) was carefully added along the walls of the separating funnel. Successive washes with distilled water were made on the solution of the previous item for separation of acetone and for the ether permanence with the carotenoid. The lower phase (water + acetone) was discarded and the ether layer was filtered through a funnel containing anhydrous sodium sulfate $\left(\mathrm{Na}_{2} \mathrm{SO}_{4}\right)$ and transferred to a $25-\mathrm{mL}$ volumetric flask, which was swelled with petroleum ether. The solution obtained was read on spectrophotometer at $449 \mathrm{~nm}$.

The carotenoids content was calculated by the equation:

$$
\mathrm{C}(\mu \mathrm{g} / \mathrm{g})=\frac{\mathrm{ABS} \times \text { dilution } \times 10^{4}}{\text { molar Abs } \times \mathrm{m}},
$$

in which $\mathrm{C}(\mu \mathrm{g} / \mathrm{g})=$ final concentration of total carotenoids (in $\mu \mathrm{g}$ of zeaxanthin per gram of yolk); $\mathrm{ABS}=$ spectrophotometer absorbance read at $449 \mathrm{~nm}$; dilution = dilution of the sample $(25 \mathrm{~mL})$; molar Abs = absorption coefficient of zeaxanthin in petroleum ether $=2348 ; \mathrm{m}=$ sample mass.

The design was completely randomized in $2 \times 6$ factorial arrangement (storage temperature $\times$ storage period), with ten replicates (each egg was considered one repetition), analyzed with yolk colour fan and three replicates in the analysis of total carotenoids. The obtained results were submitted to analysis of variance and means compared by $\mathrm{t}$ test at $5 \%$ of significance level, using Sisvar 4.3 software program(Ferreira, 2003). 


\section{Results and Discussion}

At the beginning of the experiment (time zero), the yolks showed pigmentation that ranged from 11 to 12 in colour fan, staying with close values for subsequent days (Table 2). Throughout the experiment, under different temperatures, the highest value of the visual score was 12 and the lowest was 10. It is emphasized that the colour fan only allows colours viewing represented by integers, but it was necessary to present averages containing numbers with two decimal places to show accurately what has been achieved with the repetition.

The intensity of yolk pigmentation decreased over time under different temperatures. However, this reduction was significant $(\mathrm{P}<0.05)$ only from the $28^{\text {th }}$ storage day in unrefrigerated eggs then decreasing until the $35^{\text {th }}$ day. In the eggs kept under refrigeration, the reduction was not significant $(\mathrm{P}>0.05)$ during the experimental period. Santos et al. (2009), studying the effect of temperature and storage in eggs, observed that the yolks of eggs kept at room temperature, regardless of storage time, had fewer pigmentation compared to yolks of eggs stored under refrigeration, which differs from that observed in this study, that showed no significant difference $(\mathrm{P}>0.05)$ among the temperatures studied.

The data found in this experiment confirmed an initial value of the yolk pigmentation similar to those described by Cedro et al. (2009), who found the value 11 on the yolk colour fan when they studied the intensity of pigment in $\omega-3$ enriched eggs. These authors compared the conventional eggs with enriched eggs and found greater pigmentation in enriched egg yolk. They attributed this difference to algae with high carotenoids content used in the diet of laying hens. In this work, it was not possible to associate the pigmentation of the eggs to algae, whereas the enrichment was not done with this product, but with a substrate based

Table 2 - Egg yolk degree of pigmentation

\begin{tabular}{lcc}
\hline $\begin{array}{c}\text { Days } \\
\text { A Lot (non refrigerated) } \\
X( \pm \mathrm{S})^{*}\end{array}$ & $\begin{array}{c}\text { B Lot (refrigerated) } \\
X( \pm \mathrm{S})^{*}\end{array}$ \\
\hline 0 & $11.50 \mathrm{Aa}( \pm 0.53)$ & $11.50 \mathrm{Aa}( \pm 0.53)$ \\
7 & $11.38 \mathrm{Aa}( \pm 0.52)$ & $11.50 \mathrm{Aa} \pm 0.76)$ \\
14 & $11.25 \mathrm{Aab}( \pm 0.46)$ & $11.38 \mathrm{Aa}( \pm 0.52)$ \\
21 & $11.13 \mathrm{Aabc}( \pm 0.64)$ & $11.25 \mathrm{Aa} \pm 0.46)$ \\
28 & $10.50 \mathrm{Abc} \pm 0.53)$ & $11,13 \mathrm{Aa} \pm 0.83)$ \\
35 & $10.38 \mathrm{Ac}( \pm 0.52)$ & $10.88 \mathrm{Aa} \pm 0.35)$ \\
Average & 11.02 & 11.27 \\
CV $(\%)^{* *}$ & 6.06 & 5.41
\end{tabular}

a,b,c = means followed by different lower case letters within a column differ at $5 \%$ significance level; A,B = means followed by different capital letters within a column differ at 5\% significance level.

$* \mathrm{X}=$ Average and $\mathrm{S}=$ standard deviation; $* *$ Coefficient of variation. on linseed oil. The high pigmentation found in this study is probably the consequence of adding to the ration a dyebased canthaxanthin, called carophyll.

Garcia et al. (2002) found value higher than the one of this work, scores from 14 in eggs produced from birds fed diet with canthaxanthin. The authors did not evaluate the stability of this value during the storage of eggs.

Schoner et al. (1990), comparing the efficiency of canthaxanthin $10 \%$ and citraxanthin $10 \%$ reported that, with both synthetic carotenoids added to the diets of the hens, the egg yolk pigmentation remained constant during 12 weeks of storage at refrigeration temperature, stability similar to the observed in the eggs kept under refrigeration in this study. Spada et al. (2008), by studying the intensity of pigmentation of yolks of annatto enriched eggs by using colour fan, found increased pigmentation of the red in yolks after 28 days of storage at room temperature $\left(25^{\circ} \mathrm{C}\right)$, stabilizing on the $36^{\text {th }}$ day.

The pigmentation observed in unrefrigerated eggs was lower than in those stored under refrigeration on all experiment days, but this difference was not significant $(\mathrm{P}>0.05)$ for any period studied, and this proves that the temperature did not influence the pigmentation observed with the use of the fan.

The formation of the egg yolk is an important disposing of fat-soluble residues from the layer body. The xanthophylls are fat-soluble and, when deposited in the yolk, provide characteristic pigmentation, which may be higher or lower depending on the amount of pigment ingested (Silva et al., 2000). Corn, a grain rich in carotenoids lutein and zeaxanthin have significantly contributed to pigmentation of eggs and carcasses as the main ingredient in feed for broilers and laying hens.

In total carotenoids analysis concentration of eggs stored without refrigeration, there was significant decrease $(\mathrm{P}<0.05)$ of this component already on the $7^{\text {th }}$ day of storage and this decrease was greater on the $21^{\text {st }}$ day, when it remained constant until the end of the experiment in a total reduction of $19.79 \%$ of the content (Table 3 ).

In eggs stored under refrigeration, the significant decrease $(\mathrm{P}<0.05)$ was only seen from the $14^{\text {th }}$ day, when the reduction was around $10 \%$. This content was reduced until the last week, reaching $23.57 \mu \mathrm{g} / \mathrm{g}$, which means a reduction of $17.44 \%$ of the contents of carotenoids. These results differ from those obtained by Gawecki et al. (1977) that when evaluating eggs from Leghorn birds, reported that the carotenoid content of the yolk remained stable for eight weeks of storage under refrigeration and only decreased after 15 weeks to $2^{\circ} \mathrm{C}$. The authors obtained the initial carotenoids content from $27.03 \mu \mathrm{g} / \mathrm{g}$ for the egg yolk 
with yellow carophyll, close to the value obtained on the first day of the study, which was $28.55 \mu \mathrm{g} / \mathrm{g}$.

When the levels of carotenoids among the storage temperatures are compared, significant difference was only observed on the $28^{\text {th }}$ day of experiment, when the content of non-refrigerated eggs was significantly $(\mathrm{P}<0.05)$ lower than in refrigerated eggs. On all other studied days, concentrations in eggs stored outside refrigeration were apparently lower than those under refrigeration, although this difference was not significant at the $5 \%$ significance level.

The carotenoid content determined at the beginning of the experiment $(28.55 \mu \mathrm{g} / \mathrm{g})$ was much lower than those reported by Biscaro \& Canniatti-Brazaca (2006), who analyzed eggs produced by hens fed different diets and found carotenoids concentrations ranging from 64.00 to $122.60 \mu \mathrm{g} / \mathrm{g}$. This difference may be related to the type and amount of carotenoids used in the birds feeding, to the methodology for carotenoids analysis (as in spectrophotometer quantification results can be expressed in terms of zeaxanthin, $\alpha$-carotene among others) or to the time when the tests were done (the initial quantification of this research was four days of laying).

According to Harder et al. (2007) the methodology used for determining the colour of egg yolk by means of standard colours (yolk colour fan) is extremely subjective and limited to the perception of who performs the analysis, and this can lead to errors in the results. Thus, the correlation between the yolk colour fan average and the carotenoids content over time of the experiment and under different temperatures was checked (Figures 1 and 2).

The carotenoid content and the pigmentation values determined by yolk colour fan for the egg yolks were highly correlated, both for eggs stored out in room temperature $(\mathrm{r}=0.84 ; \mathrm{P}<0.05)$ for those stored under refrigeration

Table 3 - Carotenoids content (as zeaxanthin)

\begin{tabular}{|c|c|c|}
\hline Day & $\begin{array}{c}\text { Lot A (non refrigerated) } \\
(\mu \mathrm{g} / \mathrm{g}) \\
\mathrm{X}( \pm \mathrm{S})^{*}\end{array}$ & $\begin{array}{c}\text { Lot B (refrigerated) } \\
(\mu \mathrm{g} / \mathrm{g}) \\
\mathrm{X}( \pm \mathrm{S})^{*}\end{array}$ \\
\hline 0 & $28.55 \mathrm{Aa}( \pm 0.81)$ & $28.55 \mathrm{Aa} \quad( \pm 0.81)$ \\
\hline 7 & $26.13 \mathrm{Ab}( \pm 0.94)$ & $27.47 \mathrm{Aab}( \pm 0.98)$ \\
\hline 14 & $24.91 \mathrm{Abc}( \pm 0.79)$ & $25.68 \mathrm{Abc}( \pm 0.79)$ \\
\hline 21 & $23.70 \mathrm{Ac}( \pm 0.74)$ & 24.98 Acd $( \pm 0.62)$ \\
\hline 28 & $23.12 \mathrm{Bc}( \pm 0.46)$ & $24.61 \mathrm{Acd}( \pm 0.36)$ \\
\hline 35 & $22.90 \mathrm{Ac}( \pm 0.74)$ & $23.57 \mathrm{Ad} \quad( \pm 1.30)$ \\
\hline Average & 24.89 & 25.81 \\
\hline $\mathrm{CV}(\%)^{* *}$ & 8.57 & 7.35 \\
\hline
\end{tabular}

Means followed by different lowercase letters within the same column differ at $5 \%$ significance level and means followed by different capital letters within the same column differ at $5 \%$ significance level.

$* \mathrm{X}=$ average and $\mathrm{S}=$ standard deviation

**Coefficient of variation $(\mathrm{r}=0.91 ; \mathrm{P}<0.05)$ and this correlation was higher for eggs stored under refrigeration (Figure 2). Some authors have reported similar results, a strong correlation between the concentration of pigment and pigmentation observed with the fan (Silva et al., 2000; Garcia et al., 2002).

However, Biscaro \& Canniatti-Brazaca (2006), in experiments with different diets, did not found correlation between yolk pigmentation and yolk total carotenoids content measured by spectrophotometry. Bornstein \& Bartov (1966) indicated that the visual impressions of pigmentation may not correlate with chemical analysis of pigment concentrations of the yolk, probably for two main reasons: first because the observation by colour fan does not identify which pigments are deposited in the inner parts of the yolk neither it detects unwanted reflections of colour and second because the human eye is very sensitive to a slightly darker yellow.

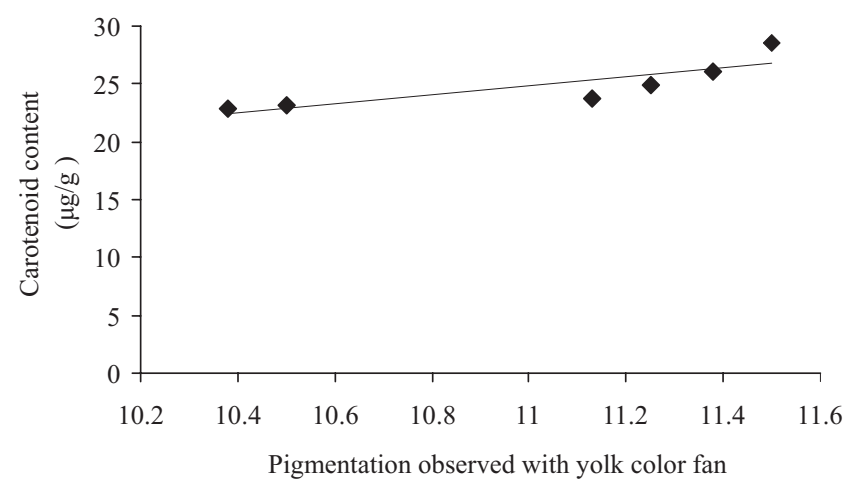

Figure 1 - Scatter diagram of Pearson correlation for eggs stored at room temperature.

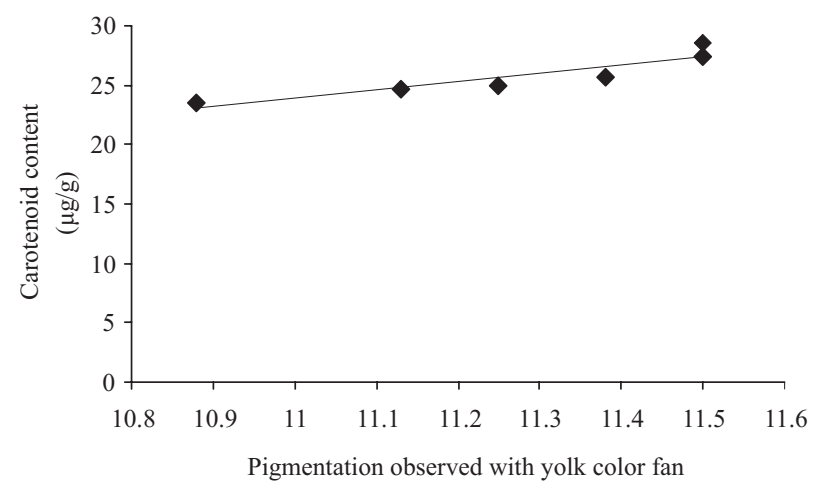

Figure 2 - Scatter diagram of Pearson correlation for eggs stored under refrigeration. 


\section{Conclusions}

The pigmentation observed in yolk colour fan is stable in refrigerated eggs and it decreases when eggs are stored at room temperature in a period of 35 days. The two temperatures affects the stability of carotenoids in spectrophotometric quantification, with a decrease in the carotenoids levels. There is strong correlation among the methods of analysis for both temperatures studied.

\section{Acknowledgments}

Laboratório Analítico de Alimentos e Bebidas (UFRRJ), Coordenação de Aperfeiçoamento de Pessoal de Nível Superior (CAPES) and for the Shintaku farm.

\section{References}

BISCARO, L.M.; CANIATTI-BRAZACA, S.G. Cor, betacaroteno e colesterol em gema de ovos obtidos de poedeiras que receberam diferentes dietas. Ciência e Agrotecnologia, v.30, n.6, p.1130-1134, 2006.

BORNSTEIN, S.; BARTOV, I. Studies on egg yolk pigmentation. I. A comparison between visual scoring of yolk colour and colorimetric assay of yolk carotenoids. Poultry Science, v.45, n.2, p.287-296, 1966

CARVALHO, P.R.; PITA, M.C.G.; PIBER-NETO, E. et al. Influência da adição de fontes marinhas de carotenóides à dieta de galinhas poedeiras na pigmentação da gema do ovo. Brazilian Journal of Veterinary Research and Animal Science, v.43, n.5, 2006.

CEDRO, T.M.M.; CALIXTO, L.F.L.; GASPAR, A. et al. Internal quality of conventional and omega-3 enriched commercial eggs stored under different temperatures. Revista Brasileira de Ciência Avícola, v.11, n.3, 2009.

EL BOUSHY, A.R.; RATERINK, R. Egg yolk pigmentation. World Review of Animal Production, v.27, p.49-62, 1992.

FERREIRA, D.F. SISVAR 4.3 - programa de análise estatística. Lavras: Universidade Federal de Lavras, 2003. (CD-ROM).
GARCIA, E.A.; MENDES, A.A.; PIZZOLANTE, C.C. et al. Efeito dos níveis de cantaxantina na dieta sobre o desempenho e qualidade dos ovos de poedeiras comerciais. Revista Brasileira de Ciência Avícola, v.4, n.1, 2002.

GAWECKI, K.; POTKANMSKI, A.; LIPINSKA, H. Effect of carophyll yellow and carophyll red added to comercial feeds for laying hens on yolk colour and its stability during short-term refrigeration. Roczniki Akademii Rolniczez W Poznaniu, v.94, p.85-93, 1977.

HARDER, M.N.C.; CANNIATTI-BRAZACA, S.G.; ARTHUR, V. Avaliação quantitativa por colorímetro digital da cor do ovo de galinhas poedeiras alimentadas com urucum (Bixa Orellana). Revista Portuguesa de Ciências Veterinárias, v.102, p.339-342, 2007.

LEMOS, P.M.M; KUHNEN, S.; PIT, F. et al. Identificação e quantificação de carotenóides de sementes de variedades locais e crioulas de milho (zea mays), desenvolvidas e cultivadas tradicionalmente por agricultores familiares de Anchieta (SC). In: REUNIÃO ANUAL DA SBPC, 58., 2006, Florianópolis. Anais... Florianópolis, 2006. (CD-ROM).

LINDEN, G.; LORIENT, D. Bioquímica agroindustrial. Revalorización alimentaria de la producción agrícola. Zaragoza: Acribia, 1996. p.43-163.

RECH, O.A. Controlando a qualidade de gema de ovos comerciais. Available at: $<\mathrm{http}$ //avicultura.com.pt/index.php?option $=$ com_content\&task $=$ category\&sectionid $=23 \& \mathrm{id}=94 \&$ Itemid $=159>$. Accessed on: Apr. 17, 2009.

RODRIGUEZ-AMAYA, D.B. A guide do carotenoid analysis in food. Washington: ILSI Press, 1999. 64p.

SANTOS, M.S.V.; ESPÍNDOLA, G.B.; LÔBO, R.N.B. et al. Efeito da temperatura e estocagem em ovos. Ciência e Tecnologia de Alimentos, v.29, n.3, 2009.

SCHONER, F.J.; HOPPE, P.P.; WIESCHE, H. Feeding trials on laying hens with a newly developed carotenoid. Muhle Mischfuttertecnik, v.127, p.487-89, 1990.

SILVA, J.H.V.; ALBINO, L.F.T.; GOIDÓI, M.J.S. Efeito do extrato de urucum na pigmentação da gema dos ovos. Revista Brasileira de Zootecnia, v.29, n.5, p.1435-1439, 2000.

SPADA, F.P.; FRANÇA, L.C.; CANNIATTI-BRAZACA, S.G. et al. Avaliação da intensidade da pigmentação vermelha das gemas de ovos crus utilizando a variável a no sistema Hunter Lab e leque colorimétrico. In: SIMPÓSIO INTERNACIONAL DE INICIAÇÃO CIENTÍFICA DA USP, 16., 2008, Piracicaba. Anais... Piracicaba: 2008. (CD-ROM). 